\title{
COVID 19: What Do We Need To Do Right Now
}

Ahmad Hassan Khan

Madam,

On $26^{\text {th }}$ of February 2020, Zafar Mirza, the Prime Minister's Special Assistant on Health confirmed via a tweet first two cases of coronavirus in Pakistan, first case was reported from Karachi and second case was reported from Islamabad, both were recently returned from Iran. ${ }^{1}$ Within less than a week, cases in all provinces were confirmed. On March 11, 2020 WHO, declared COVID-19 a pandemic and it has impacted more than 195 countries worldwide. ${ }^{2}$ Various necessary steps were taken by Pakistan Government to minimize the spread of the virus and more importantly making arrangements for treatment of corona patients at healthcare facilities. ${ }^{3}$ The number of confirmed COVID-19 cases in Pakistan has crossed 148,921 with 56,3900 recoveries and around 2,839 deaths in the country, whereas number of confirm patients in Punjab have approached to 55878 till 15 June $2020 .{ }^{4}$ There is a dire need to sensitize masses to take necessary precautions for stopping transmission of virus as during the recent relaxation in the lock down just before Eid major violations of the Standard operating Protocols were observed throughout the country. Bed occupancy for example is almost at maximum capacity at Divisional headquarters Hospital Sargodha. The coming few weeks are going to be extremely challenging for the doctors as they have to deal with the dilemma of counseling the raging attendants also. Unless a very close eye is kept on the evolving situation there is a chance of chaos at hospitals.
Limited Research has been done and published locally so far in Pakistan. There is a need to encourage health care professionals to conduct various research projects related to Covid-19 as this will in turn help the health force to target the observed deficiencies found hence helping the health force to provide better care of suffering patients.

Conflicts of Interest: None.

\section{REFERENCES}

1. Dawn, Pakistan confirm first two case of corona virus, govt says “ no need to panic"(online) Updated February 26, 2020. Available from URL: https://www.dawn.com/news/1536792 (Date of Access: June 15, 2020)

2. Mubeen SM, Kamal S, Kamal S, Balkhi F. Knowledge and awareness regarding spread and prevention of COVID-19 among the young adults of Karachi. J Pak Med Assoc. 202070 (Suppl 3)(5):S169-S174. doi: 10.5455/JPMA.40.

3. Mukhtar S. Preparedness and proactive infection control measures of Pakistan during COVID-19 pandemic outbreak. Res Social Adm Pharm.. 2020. doi10.1016/j.sapharm.2020.04.011

4. Government of Pakistan. Pakistan cases details. Available from URL:http://covid.gov.pk/stats/pakistan (date of Access: June 15,2020

\section{Correspondence:}

Dr Ahmad Hassan Khan, $M B B S$, $F C P S$

Associate Professor Surgery

Sargodha Medical College,

University of Sargodha

Email: docahmadhassan@hotmail.com 